\title{
Dilemma in Relations? A Socio-historical Study of Ethiopian Orthodox Attitudes towards Protestant Christianity
}

\author{
Eunhye Chang
}

\section{$1 \quad$ Introduction}

Where is the root of Christianity in Africa? While other African countries struggled under the colonial yoke, Ethiopia preserved a unique Christianity and its culture. Christianity in Ethiopia dates to the 4th century when the King 'Ezana first adopted Christian faith. Being influenced by various theological orientations, the early Ethiopian Christianity established its own distinctive heritage and tradition. Later, Catholic and Protestant Christianity were introduced. Among these churches of different traditions, the Ethiopian Orthodox Täwaḩədo Church, as a state religion, has had a dominant influence over every sphere of Ethiopian society.

The past history of Ethiopia provides that the influence of Catholicism and Protestantism within Ethiopian territory resulted in the conflict with the Ethiopian Orthodox Church and consequently in developing a xenophobic attitude in Ethiopian society towards Western forms of Christianity and their missionaries. ${ }^{1}$ Catholicism and Protestantism are perceived as "foreign,

1 According to most recent Ethiopian national census of 2007, Ethiopian Christianity includes Orthodox, Protestants, and Catholics.

\begin{tabular}{|c|c|c|c|c|c|c|c|}
\hline Year & $\begin{array}{l}\text { Total } \\
\text { population }\end{array}$ & Orth & Protestant & Catholic & Islam & $\begin{array}{l}\text { Traditional } \\
\text { religion }\end{array}$ & Others \\
\hline 007 & 73,7 & $\begin{array}{l}32,092,182 \\
(43 \cdot 5 \%)\end{array}$ & $\begin{array}{l}13,661,588 \\
(18.6 \%)\end{array}$ & $\begin{array}{l}532,187 \\
(0.7 \%)\end{array}$ & $\begin{array}{l}25,037,646 \\
(33.9 \%)\end{array}$ & $\begin{array}{l}1,956,647 \\
(2.65 \%)\end{array}$ & $\begin{array}{l}470,682 \\
(0.6 \%)\end{array}$ \\
\hline 1984 & $38,203,682$ & $\begin{array}{l}20,637,362 \\
(54 \%)\end{array}$ & $\begin{array}{l}2,094,371 \\
(5.5 \%)\end{array}$ & $\begin{array}{l}374,880 \\
(0.9 \%)\end{array}$ & $\begin{array}{l}12,569,995 \\
(32.9 \%)\end{array}$ & $\begin{array}{l}2,213,665 \\
(5 \cdot 7 \%)\end{array}$ & $\begin{array}{l}249,043 \\
(0.65 \%)\end{array}$ \\
\hline
\end{tabular}

Protestants radically increased from $5.5 \%$ to $18.6 \%$ of the total population from 1984 to 2007 . Most of this increase seems to have come at the expense of the Ethiopian Orthodox Church, 
unfamiliar, and heretical" 2 religions. More recently, it is observed that the Ethiopian Orthodox Church has tended to be associated with protection and hesitation in developing the relation with Western forms of Christianity within Ethiopia as well as in International context.

This paper explores the reasons why the Ethiopian Orthodox is reluctant to engage with Western forms of Christianity within Ethiopia as well as in global context. In order to investigate this question, three subsidiary questions are asked as follows. First, what are the major issues that resulted in the conflict between the Ethiopian Orthodox Church and Western missions? Secondly, what is the Ethiopian Orthodox perception of the Western forms of Christianity, especially Protestant Christianity? ${ }^{3}$ Finally, what kind of engagement the Ethiopian Orthodox Church has developed with other churches of different Christian tradition within Ethiopia as well as in global context?

For answering these questions, the Ethiopian Orthodox interaction with Western missions in the past and in current context are reviewed based on the literatures related to history, theology, missiology, and anthropology. Qualitative research method based on thirty-two personal interviews is employed to analyze Orthodox Ethiopians' attitudes towards Western forms of Christianity at the grass roots level.

\section{The Ethiopian Orthodox Encounters with Western Christianity: A Historical Outline}

\subsection{Encounters with Catholic Missions}

There have been many studies discussing the main causes that contributed to developing the tension between the Ethiopian Orthodox Church and Western Christianity. ${ }^{4}$ When the Portuguese Catholic missions ventured into the coun-

whose share declined from $54.0 \%$ to $43.5 \%$ in the same time span. It is expected that the growth of Protestants will continue, leading to a deep shift in Ethiopia's religious landscape: Jörg Haustein, Writing Religious History. The Historiography of Ethiopian Pentecostalism (Wiesbaden: Harrassowitz, 2011), 18.

2 Tibebe Eshete, The Evangelical Movement in Ethiopia. Resistance and Resilience (Waco, TX: Baylor University Press, 2009), 309.

3 In the last decades, it was observed that there has been more conflict between the Orthodox and Protestant churches due to the radical growth of Protestant churches. In order to ask the question about the Orthodox perception for Western Christianity, only Protestants are included for this research.

4 For further discussion, see: Arnold Jones and Elizabeth Monroe, A History of Ethiopia (Oxford: Clarendon Press, 1935), 100-101; Donald Crummey, Priests and Politicians. Protestant and 
try in the 16th century, they came into significant conflict with the Ethiopian Orthodox Church. Leonardo Cohen writes that "[i]n 1520, the first Portuguese delegation reached Ethiopia, which became a center to a most interesting encounter between religions and cultures." ${ }^{5}$ Catholic mission's methods to establish Catholicism as the state religion during ${ }^{1555^{-16}} 6$ provoked fierce opposition from Ethiopian monks, ultimately leading to a widespread civil war. This resulted in the Jesuits' expulsion from Ethiopia.

To explain the main problems of the clash between the Ethiopian Orthodox Church and the Catholics during 16th and 17th centuries, some scholars indicate the following three points: Catholic missionaries' methods to subordinate the Ethiopian Ecclesiastical hierarchy, Ethiopian Christological doctrine, and Ethiopian religious practices under the authority of the Catholic Church. ${ }^{6}$ Many of them focus on mainly discussing the difference between their Christological positions, especially regarding the nature of Christ as the central issue of the conflict between the two parties. ${ }^{7}$

More recently others claim that the conflict between missionaries and the Ethiopian Orthodox Church was due to the missionaries' ignorance of the fact that they were actively involved in challenging the Ethiopian Church's "existing political and ecclesiastical powers or religious identity" and "humiliating the ruler of the country" in order to achieve their aims. ${ }^{8}$ It was believed by the Ethiopians that missionaries "threatened the Ethiopian nation." ${ }^{\text {"Therefore, the }}$

Catholic Missions in Orthodox Ethiopia 1830-1868 (Oxford: Clarendon Press, 1972), 6; Leonardo Cohen, The Missionary Strategies of the Jesuits in Ethiopia (1555-1632) (Wiesbaden: Harrassowitz, 2009), 27; Ayele Teklehaymanot, "The Struggle for the 'Ethiopianization' of the Roman Catholic Tradition," in The Missionary Factor in Ethiopia. Papers from a Symposium on the Impact of European Missions on Ethiopian Society. Lund University, August 1996, ed. Getatchew Haile, Aasulv Lande and Samuel Rubenson (Frankfurt am Main: Peter Lang, 1998), 135-154; Calvin Shenk, "The Ethiopian Orthodox Church: A Study in Indigenization," Practical Anthropology 16 , no. 3 (1988): 259-278.

5 Cohen, The Missionary Strategies, xv.

6 See Jones and Monroe, A History of Ethiopia; Crummey, Priests and Politicians.

7 Stephen J. Strauss, Perspectives on the Nature of Christ in the Ethiopian Orthodox Church: A case study in contextualized theology. Ph D. diss. (Deerfield, Illinois: Trinity International University. 1997), 1. See also Ethiopian scholars' arguements on the Ethiopian Orthodox Christological position: Aymoro Wondmagegnehu and Joachim Motovu, The Ethiopian Orthodox Church (Addis Ababa: Ethiopian Orthodox Mission, 1970) Ayele Teklehaymanot, The Ethiopian Church and its Christological Doctrine (Addis Ababa: Graphic Printers, 1981).

8 Sven Rubenson, The missionary factor in Ethiopia: consequences of a colonial contest. In The missionary factor in Ethiopia: Papers from symposium on the impact of European missions on Ethiopian society, Lund University, August 1996, ed. Getachew Haile, Aasulv Lande, and Samuel Rubenson, 57-70. (Frankfurt am Main: Peter Lang, 1998), 69.

9 Ibid., 70. 
incident of Catholic interlude left something in the heart of Ethiopian people, which became one of the factors in the development of very strong antipathies towards Western missions. The sore feelings engraved in the Orthodox Ethiopians is found by calling the Catholics as Ș̈̈rä Maryam, 'enemies of Mary.'10 This labeling became "a generic tag to categorize all non-Orthodox Christians." one who turned to Catholicism was also called kätolikawyan which became a generic term for "heterodoxy, or even worse, apostasy."12 Thus, for Ethiopians, the one who joins Catholics in Ethiopian society is assumed to be abandoning the Orthodox faith and his national identity. ${ }^{13}$

\subsection{Encounters with Protestant Missions}

In relationship with the Ethiopian Orthodox Church, the early Protestant missionaries in Ethiopia avoided confronting the ancient Ethiopian Church, but pursued renewal and reform from and within the Church. However, the mission decree published by the Ethiopian government in 1944 directed all Protestant missionary activities to non-Orthodox areas, which led to winning converts among the Orthodox. These converts became members of Protestant groups with foreign mission affiliations. ${ }^{14}$ Western mission agencies and their related churches started growing into many non-Orthodox areas in the southern and western region of Ethiopia.

The growth of Protestant churches was strongly opposed by the Orthodox church leadership, in cooperation with local administrative authorities in the south, who made a protracted effort to curtail the planting of evangelical churches. The Orthodox persecution of Protestant Christians spread out within the country to the extent that Protestant evangelists and local church leaders were imprisoned and beaten. As recently as 2002, the evangelical churches have experienced a martyrdom arising from the Orthodox church leadership. ${ }^{15}$

In order to look down for Protestant Christians, the word Pente was coined during the Communist regime in the years 1978 and 1979.

The government, the local leaders and society at large determined then, once and for all to expel anyone found to be Protestant. [...] The gov-

\footnotetext{
10 Tibebe Eshete, The Evangelical Movement, 25.

11 Ibid. 25.

12 Bahru Zewde, Pioneers of Change, 71.

13 Ibid., 71.

14 Tsega Endalew, "Protestant Mission Activities and Persecutions in Bahər Dar, 1968-1994. A Chronicle," in Ethiopia and the Missions. Historical and Anthropological Insights, ed. Verena Böll et al. (Münster: Lit, 2005), 210.

15 Balisky, Wolaitta Evangelists.
} 
ernment could not tolerate the Protestant meetings as it suspected they fostered affiliations with the West. Under cover from the government, people rose in mob actions with the notorious slogan 'Down with Pente!', where 'Pente', a corrupt form of Pentecost, was a derogatory name given to the Protestants. Anti-Protestant propaganda was more pronounced at the local level. Protestantism was considered a foreign religion, opposed to the ancient Orthodox faith. ${ }^{16}$

From the Ethiopian Orthodox perspectives, the missionary activity is often considered as shrinking the power of the Ethiopian Orthodox Church. The growth of Western Protestant mission agencies and their related churches within the country is seen as a threat to the Ethiopian Orthodox Church. Getatchew Haile contends that "Ethiopian Orthodox Christianity is an embedded nationalism based on culture, religiosity, and identity: religion has become the foundation of patriotism, nationalism and personal identity." To challenge Ethiopian religion is to challenge the makers of Ethiopian patriotism, nationalism, and identity. ${ }^{17}$ Thus, Western Protestant missionaries' evangelistic activities within the Ethiopian territories are considered by the idea of sheep-stealing. This created sore feelings within the Orthodox Ethiopians, who believed that missionaries had only come to take away its flock. ${ }^{18}$

In summary, it is reviewed how the Catholic missionaries' activities to abolish the long-established Ethiopian Christian traditions during 1555-1632 and the sudden expansion of Protestant local churches in Ethiopian territory were considered to be a threat to Ethiopia, its church, its culture, and ultimately its identity. As a result, both Catholicism and Protestantism are engraved as negative stereotype of "foreign, unfamiliar, and heretical"19 religion in the heart of Orthodox Ethiopians. This incurs a xenophobic attitude in Ethiopian society towards Western Christianity, including Protestant and Catholic Christians, and missionaries as well as anything foreign.

\footnotetext{
16 Tsega Endale, "Protestant Mission Activities," 210.

17 Getatchew Haile, "The Missionary Dream," 3.

18 Taddesse Tamrat, "Evangelizing the Evangelized. The Root Problem between Missions and the Ethiopian Orthodox Church," in Ethiopia and the Missions. Historical and Anthropological Insights, ed. Verena Böll et al. (Münster: Lit, 2005), 3०.

19 Tibebe Eshete, The Evangelical Movement, $3 \circ 9$.
} 
The Ethiopian Orthodox Attitudes towards Protestant Christianity: A Sociological Study

Historical study provides scholars' discussion on the main causes that contributed to developing the Orthodox strong antipathy against foreigners and foreign Christianity. In order to find out the actual Ethiopian Orthodox attitudes towards Western Christianity, especially Protestant Christianity and Protestant Christians at the grassroots level, thirty-two Orthodox young people in Addis Abäba whose ages ranged from 18 to 32 were selected ${ }^{20}$ and interviewed. ${ }^{21}$

Table 11.1 illustrates the most frequently used words by which thirty-two Orthodox young adults refer to Protestant Christianity. The list of the words implies the negative images attached to Protestant Christianity.

The most prominent image attributed to Protestant Christianity is identified as the foreign and heretical religion. The report of an eighteen-year-old boy well represents the negative association related to Protestant Christianity as foreigners' religion.

At home, I do not dare to talk about Protestant Christianity. Since it is regarded as Färänği [foreigner] religion, I am not allowed to talk about it. In the history of Ethiopia, Orthodox Christianity existed for thousands years, which was the foundation of our society. Protestant Christianity was brought by the whites later by using programs like a project in order to convert Ethiopian people to the Protestant faith. Thus, Protestant Christianity is new religion that Färänği tries to win over the Orthodox.

The second most prominent perception is related to the Protestant missionary methods using material aid, such as money, funds, wheat, corn, food, sälbağ (second-hand clothes), various materials, financial support, feeding, and sponsoring, which were all mentioned in the interview narratives. According to a twenty-two-year-old woman's report,

20 In pursuit of the qualitative research, the population for this research consists of young adults in Addis Abäba who self-identified their Orthodox faith and were affiliated to Orthodox churches in Addis Abäba. Their names are confidentially kept in order to encourage the interviewees to freely express their understandings, thoughts, and experiences without imposing the researcher's own perceptions on the interviewees.

21 By employing the Nvivo 10 software program, the interview narratives were encoded and categorized according to the words that respondents used in describing their impression of Protestant Christianity. The most prominent words were analyzed to provide the images attached to Protestant Christianity and Protestant Christians. 
TABLE 11.1 Negative attributions attached to Protestant Christianity

Protestant Christianity as

Number Number of

of respon- references

dents

$\begin{array}{lll}\begin{array}{l}\text { the religion of Färänği (Foreigner), the Whites, } \\ \text { missionaries }\end{array} & 29 & 69 \\ \begin{array}{l}\text { the religion of deceiving / lying people in mission- } \\ \text { ary intention }\end{array} & 20 & 23 \\ \begin{array}{l}\text { the religion using material aid in missionary } \\ \text { methods }\end{array} & 15 & 23 \\ \text { enemy of the Orthodox church } & 15 & 22 \\ \begin{array}{l}\text { mete (new religion imported from abroad) } \\ \text { Satanic religion }\end{array} & 15 & 22 \\ \text { the religion of cultural invasion } & 9 & 23 \\ \text { the religion of Sheep stealing } & 5 & 7 \\ \text { wrong / bad / false / disgusting / fake religion } & 1 & 2 \\ \end{array}$

[w]e thought that Orthodox people converted to Protestant Christianity because the Färänği (foreigners) convinced them to accept their religion by giving wheat or money as the reward for conversion. So, missionaries are regarded as the agents who deceive Ethiopian people for changing our religion into Protestant Christianity [...] I used to criticize the Pentewočc (Protestant Christians) for stealing sheep from the Orthodox Church.

From the Orthodox perspective on how they use material aid, missionaries are often associated with the negative images of deception and sheep-stealing.

The third stems from the theological difference by which Protestant Christianity is called as the enemy of Orthodox because of expressing their faith in Jesus Christ, not worshiping Mary as well as angels. Thus, "Protestants are labeled as Mänafəq [apostate] or 'the enemy of Mary, the enemy of saints and angels.' Protestants are not considered good persons but deniers of the Orthodox faith."22

The fourth most common negative association for the Protestant Christianity is that it is perceived as Mete, which means that

22 Interview: The narratives of a twenty-six-year-old man. 
TABLE 11.2 Negative attributions attached to Protestant Christians

\begin{tabular}{lll}
\hline $\begin{array}{l}\text { Negative attributions attached to Protestant } \\
\text { Christians }\end{array}$ & $\begin{array}{l}\text { Number of } \\
\text { respondents }\end{array}$ & $\begin{array}{l}\text { Number of } \\
\text { references }\end{array}$ \\
\hline $\begin{array}{l}\text { Pente } \\
\text { Hold bad things / make mistakes / lost / defiled / } \\
\text { wrong / disgusting }\end{array}$ & 27 & 160 \\
Hatred & 17 & 42 \\
$\begin{array}{l}\text { Denier of the Orthodox Faith / Mänafaq (Apos- } \\
\text { tate) / enemies of Mary / enemies of God }\end{array}$ & 10 & 31 \\
Slave of material aid or money & 7 & 14 \\
$\begin{array}{l}\text { Liar } \\
\text { Fanatical attitudes regarding speaking up about }\end{array}$ & 6 & 11 \\
Jesus and reading Bible & 6 & 7 \\
Serve Satan & 4 & 6 \\
Betrayal of Ethiopian identity & 5 & 6 \\
Witchdoctor & 1 & 5 \\
\hline
\end{tabular}

it was invented and imported from abroad. It is the religion of Färänği that recently came into the country. Thus, it is not counted as the right religion in Ethiopia as the same as Orthodox and Islam because it did not come from the past generation. ${ }^{23}$

Furthermore, Protestant Christianity is considered a religion brought by Färänğočč, foreigners, who intended to defile Ethiopia and Ethiopian culture. ${ }^{24}$ Protestant Christianity is seen as a cultural invasion of Färänği. ${ }^{25}$

Table 11.2 provides different types of stigmas attached to Protestant Christians. The most prominent image mentioned in the interviews was the labeling of Protestant Christians as Pente in the Ethiopian language in order to stigmatize them within the Orthodox community. ${ }^{26}$ The narratives of a twenty-sixyear-old man describe the second most popular misconception:

23 Interview: The narratives of a thirty-year-old woman.

24 Interview: The narratives of a twenty-three-year-old man.

25 Interview: The narratives of a twenty-two-year-old woman.

26 Interview: The narratives of a twenty-two-year-old woman. 
Protestant Christians are counted as the opponent of the Orthodox faith since they abandoned what the Orthodox worship-Mary, saints, angels, and martyrs. They are labeled as Mänafaq [apostate] or 'the enemy of Mary, the enemy of saints, and angels.' Pentewočč are not considered good persons but deniers.

As the third most common misperception, Protestant Christians were criticized for using material aid in missionary methods. Protestant converts are called slaves, while missionaries are liars. Protestant Christians were also misunderstood as serving Satan. Orthodox people condemn Pentecostal style of prayers as Satanic ritual. Another negative perception comes from Protestant believers' fanatical attitudes of speaking up about Jesus and Bible reading, which are considered as the marks of counteraction against Orthodox practices. Ordinary Orthodox believers often avoid talking about Jesus in order to differentiate themselves from Protestant believers emphasizing on Jesus, but prefer showing their veneration to Mary, saints, and angels in daily life. Some also believe that the authority of Bible reading belongs to the priests, not the ordinary people. Thus, if someone shows overconfidence in talking about Jesus and reading the Bible in public, he/she might be criticized as the enemy of the Orthodox faith, the enemy of Mary, or the apostate.

Four respondents mentioned that becoming a Pente (Protestant Christian) is equated to abandoning the Ethiopian nationality. An eighteen-year-old boy commented that the "Orthodox may consider that becoming a Pente means betraying the Ethiopian nation and accepting the religion of Färänği for the sake of the material benefit." One respondent's answer provided the extreme case: "My family even claimed that the Protestants are țänkway [witchdoctor]."

In reviewing the interview narratives, it is noteworthy to find that the words, hate and hatred were used by seventeen respondents (in thirty-one occurrences) in uncovering their rancor towards Protestant Christians. These respondents expressed that the feeling of hatred against Protestant Christianity and Protestant Christians had been passed down from the teaching of the old generation. The narrative of a twenty-six-year-old man offered this:

My parents had intense hatred towards Protestant Christianity. So did I. However, I could not provide a clear answer as to the reason why I hated Protestant Christianity. Without knowing it, there was hatred deeply residing inside of me [...] In Ethiopia, a religion is inherited from the family in most cases. Prejudice toward Protestant Christianity is inherited from parents. I think that this impacted my perspectives toward Protestant Christianity. 
Respondents are frequently instructed by their parents and their Orthodox community how to behave towards Protestant Christians. The most prominent reactions towards Protestant Christians are mentioned by an eighteen-year-old boy saying that

My parents asked me to be distant from Pente or to look down on Pente. Even in the Orthodox church, they preach to us not to do anything with Pente and not to talk to Pente. They teach that Pențewočč are holding bad things [...] This is the current situation against Protestant Christians.

Although many of the respondents reported on negative images associated with Protestant Christianity and Protestant Christians, six of thirty-two respondents provided that they did not have negative attitudes towards Protestant Christians. They attributed the following factors as contributing to their good impressions: Protestant ethical lifestyles, their courage in keeping the faith firm in Christ despite of persecution, and the gospel message they are witnessing.

In summarizing the findings of the Orthodox perception of Protestant Christianity, they do not remember the Catholic missions' interlude happened in Ethiopian history. They even do not talk about any theological controversy that most scholars discuss. It is significant to find that Orthodox Ethiopians see Western Christianity as foreign and heretical religion, which becomes the major cause to prevent Ethiopian Orthodoxy from interacting with other foreign churches within Ethiopia.

\section{Recent Developments of Ethiopian Orthodox Relations with Other Christian Churches}

\subsection{Current Interactions of Ethiopian Orthodoxy with Catholic and Protestant Churches}

Although there was no established tradition of making peaceful relations among Ethiopian Christianity, the cumulative sequence of events within Ethiopia for the last decades led to a new orientation and development of the Ethiopian Christian life.

Especially during the Communist regime, three Ethiopian Churches were coerced into cooperation towards the communist propaganda discrediting Christian Churches' activities. ${ }^{27}$ The Ethiopian Evangelical Church of Mekane

Petros Berga, Ecumenical Dialogue, 298. 
Yesus (ЕесмY) initiated to facilitate a series of seminars and workshops to study what it meant to be a Christian in this particular socialist context. Although small numbers of people from one department of Ethiopian Orthodox Church came, however, for the first time, in Ethiopian church history, the representatives of evangelical churches, the Catholic Church came together to discuss the common issues of the time. On this occasion, it was suggested the formation of the Council for Cooperation of Churches in Ethiopia. It was the common concern, how to survive in a Socialist State, which brought them together. Unfortunately, the Council did not have a long life because the Orthodox and the Catholic Churches withdrew. ${ }^{28}$

The severe drought in 1984 also united three churches again to work together for helping the people in the extremely damaged area. They established Joint Relief Program on the national level and appealed Ethiopian draught situation to the outside world. EЕCMY sent the message to the World Lutheran Federation; the Ethiopian Orthodox Church to World Council of Churches (wCC); Catholics to the Catholic Relief Services. The representatives of these three churches put all the effort in travelling overseas to get international aid to distribute the food to the people in the damaged area. Through the support of the Inter-Church Aid Commission and the programs of the wCc, the Ethiopian Orthodox Church implemented her development schemes in the areas such as its relief, rehabilitation and development programs. ${ }^{29}$ This relationship enhances the Orthodox church to have the opportunity in establishing friendly relations with many different churches and Christian associations in international context.

Continuous effort to establish an informal relationship with the leaders of the Orthodox churches can pave the way for building good relationship with three churches. EECMY endeavored to establish contact with some of the leaders in the Orthodox church on a personal basis. Especially, Rev. Gudina Tumsa believes that "this type of informal relationship will possibly lead to official dialogue between the two Churches." ${ }^{30}$

The current situation of the globalization process in Ethiopia presents new opportunities for the Ethiopian Orthodox Church to associate with foreign churches in international context. The Ethiopian Orthodox Church is one of

28 The Gudina Tumsa Foundation, ed., The Life and Ministry of Gudina Tumsa. Lectures and Discussions (Hamburg: WDL-Publishers, 2007), 136-137.

29 The Ethiopian Orthodox Tewahedo Church, ed., The Ethiopian Orthodox Tewahedo Church. Faith, Order of Worship and Ecumenical Relations, 2nd ed. (Addis Ababa:Tansae Publishing House, 1996), 140.

The Gudina Tumsa Foundation, The Life and Ministry, 136. 
the founding members of the World Council of Churches ${ }^{31}$ instituted in 1948 in Amsterdam. From the beginning, the Ethiopian Orthodox Church claims that it has played a significant role in the work of the WCC by having twelve delegates sit in the general Assembly and an additional two representatives in the Central Committee. ${ }^{32}$ Later, in 1974, EECMY among the Evangelical churches in Ethiopia joined the member of the wcc. The fellowship of the All Africa Conference of Churches holds the theological conferences, where the Ethiopian Orthodox Church participates to build a closer relation and mutual sharing of experiences among the churches in Africa. ${ }^{33}$

Since 1961, the Ethiopian Orthodox Church actively took part in the PanOrthodox meeting which promotes the unity of the Oriental Orthodox churches (Armenian, Coptic, Syrian, Ethiopian and Indian) and the Eastern Orthodox churches in the realm of ecumenical movement. ${ }^{34}$ They tried to find the ways of resolving the Christological difference and an eventual reunion of the Chalcedonian Orthodox churches and the Non-Chalcedonian churches. ${ }^{35}$

More recently, the Ethiopian Orthodox Church and the Ethiopian Evangelical churches have participated in Lausanne-Orthodox Initiative, ${ }^{36}$ which was born of informal conversations between leaders of the Lausanne Movement and Orthodox observers at the 2010, the third Lausanne Congress in Cape Town. These conversations led to making a steering committee to explore how to increase mutual understanding and a healing of wounds, in order to collaborate more effectively in the area of God's mission. Subsequent regional consultations were held in Albania (2014), Finland (2015), Ethiopia (2016),

This Ecumenical Council has various functions and purposes, the first and the foremost of which is to call the churches to the goal of visible unity in one faith and in one eucharistic fellowship in expressed worship and in common life in Christ, and to advance towards that unity in order that the world may believe. In addition to this, the Inter-Church Aid is the other main function of the wCC's general purposes.

The Gudina Tumsa Foundation, The Life and Ministry, 140.

33 Ibid., 141-142.

34 Ibid., 143-144.

35 Ibid., 143 .

36 The Lausanne-Orthodox Initiative seeks to mediate reconciliation and healing between the Orthodox communities and Evangelical communities. Over many centuries, and particularly during the twentieth century, there has been both the persecution of Evangelical Christians by Orthodox communities and the demonization of the Orthodox faith by Evangelical missionaries. The Lausanne-Orthodox Initiative tries to find a way to build constructive relationships of trust and respect between the two communities: Danut Manastireanu, "Lausanne Initiative to Bring together Orthodox and Evangelical Leaders in Ethiopia," Lausanne Orthodox Initiatives, accessed 15.06.2019. URL: https://danutm .wordpress.com/2016/o3/21/lausanne-initiative-to-bring-together-orthodox-and-evangeli cal-leaders-in-ethiopia. 
Cambridge (2017), and Boston (2018) to bring together Orthodox and Evangelical leaders in Ethiopia. In October 2016, the Ethiopian Orthodox Church and the Ethiopian Evangelical Church hosted the Lausanne-Orthodox Initiative in Ethiopia. Sixty Orthodox and Evangelical church leaders, theologians and mission workers from other parts of Ethiopia and the world gathered in Addis Abäba seeks to mediate reconciliation and build constructive relationships of trust and respect between the Orthodox churches and the evangelical churches.

\subsection{Developing Ways to Achieve a Constructive Relations with Western Churches}

Inter-Church activities such as WCC and other international meetings as well as cooperative meetings within the country offer the opportunities for the representative leaders from the Ethiopian Orthodox Church, Catholics, and Evangelicals to sit together at the executive committee, without tension and without conflict, and share fellowship and prayer, and discuss their faith, missions and evangelism, and development. Although there has been tension between the Ethiopian Orthodox Church and Western missions and their related churches at the grassroots level, this indicates that it is possible to find a way to deconstruct negative stereotypes of the past and reconstruct the Inter-Church relation within the country first and then in the global context.

How to develop the ways for the Ethiopian Orthodox Church to make a constructive relation with Western forms of Christianity? From the evidence of current Orthodox Church's interaction with other churches within Ethiopia and in international context, it shows that there is "a negotiable possible middle way" 37 to bring Christian churches of three traditions together so that it can mediate the three Christian churches by providing the moral guidance and emotional motivation to bring the peaceful relation.

International conferences as well as the national level of cooperation work provided a suitable neutral place for the leaders from the three churches of Ethiopia to build constructive relation. As for the future plan of three churches' cooperation work, Dr. Wakseyoum Idossa, the director of Peace Office of EEC$\mathrm{MY}^{38}$ suggests establishing the Council of Churches in Ethiopia. He says that

37 Petros Berga, Ecumenical Dialogue, 63.

38 The евсмy Peace Office was established 1993. Its objective is to build a peaceful society where all people have equal access to national resources and promote unity based on equality. It collaborates with various government offices, local and other partner churches, faith-based institutions and civil society organizations in carrying out its work, Tsion Alemayehu, "Ethiopian Church Fosters Peace and Reconciliation in Gambella," The 
in 2016 there was an informal discussion among the two representatives from the ЕотС and ЕЕсмY, and Catholics who met together and tried to establish the Council of Churches in Ethiopia. Eventually it did not turn out to be an agreement among the three Churches due to the EотC's indecision and hesitation. ${ }^{39}$

Nevertheless, several points were suggested for constructing positive InterChurch relation. First of all, it is primary task that Christian identity needs to be reconstructed through this Council of Churches. Over the centuries, being closely tied to the state, the Ethiopian Orthodox Täwahədo Church has had a dominant influence over every sphere of Ethiopian society by setting "the cultural delimiters, legislating norms, and defining national identity." 40 Ethiopia's Marxist regime (1974-1991) and the federal form of government established in 1991 disestablished the political power of the Ethiopian Orthodox Church and sanctioned this separation between the church and the state, whose sudden implementation had a major impact on the religious map in Ethiopian society.

Secondly, there should be revision or correction on the way of Protestant churches' sharing the gospel message with others. The findings from the literature and the interviews indicate the Ethiopian Orthodox Church's bitter responses to Western missions and their related churches were caused by their evangelistic methods. The negative stereotypes engraved in Orthodox Ethiopians' heart also brought about the unnecessary conflict and tension between the Orthodox and the other churches. Dr. Wakseyoum says, "those вотc, Catholics, evangelicals, and all of us have one country. We have the right to promote our religious faith without conflict. We have to find a way to live together peacefully, to tolerate each other, to collaborate together to reach out people in Christian faith."41

Thirdly, once the Council of Churches in Ethiopia is established, it will be able to provide a platform for the Ethiopian Orthodox Church to cooperate with other churches. The current Ethiopian Orthodox Church is challenged to revitalize its tradition and identity relevant in the current context as well as to recuperate her competitive spiritual implications and practical participation in a public sphere. In order to do this, the Orthodoxy needs to be flexible to open to new ideas and pluralism, and to engage with foreign churches for the task

Lutheran World Federation, published 07.07.2016, URL: https://www.lutheranworld.org/ news/ethiopian-church-fosters-peace-and-reconciliation-gambella.

39 Dr. Wakseyoum Idossa, Director of Еесмy Peace Office, Interview on 28.o9.2018.

40 Tibebe Eshete, The Evangelical Movement, 310.

41 Dr. Wakseyoum Idossa, Director of Е Есмy Peace Office, Interview on 28.o9.2018. 
of performing valuable public services. It is good for the Ethiopian Orthodox Church to work together with the Council of Churches in order to address the issues like peace, drought, development projects, and national crisis are good themes in public space.

Finally, it is necessary to train the mission-minded leaders within each Christian church to promote to effect attitudinal and behavioral transformation of their members. From reflecting the interview findings and the recent InterChurch meetings and conferences, there is the huge gap between the Orthodox church leaders present in international conferences and the ordinary Orthodox people in their attitudes towards Western Christianity. In order to provide a way to deconstruct each other's negative stereotypes, it is helpful to find "the possible narratives" that can provide the good examples in which the Orthodox and Two other churches or the members of these churches cooperated together in history. ${ }^{42}$

Needless to say, there are conflicts and different opinions within the Orthodox church as well as within Evangelicals regarding interaction with other churches of different faith. As cumulative sequence of Inter-Church activities within the country were successfully initiated by building informal relations between the Orthodox and the evangelical churches, it requires lots of effort in fostering continuing interaction and building a friendly relation between the churches within Ethiopia as well as in international context.

\section{Conclusion}

The Ethiopian Orthodox Church has been resistant to engage with Western forms of Christianity within Ethiopia. The past history reveals that the Orthodoxy has tended to be associated with protection from the foreign invasion and xenophobia. In ordinary Ethiopian Orthodox perception, Western forms of Christianity is identified as illegitimate and hatred religions, which prevented them from interacting with Protestant Christians and their churches. Although there are many challenges to rebuild Christian identity embracing three Christian traditions within Ethiopia, it is still possible when the churches put an effort on working together to develop a constructive relations and reconciliation for the common purpose for the Gospel within Ethiopia as well as in global context. 


\section{List of References}

Ayele Teklehaymanot. “The Struggle for the 'Ethiopianization' of the Roman Catholic Tradition." In The Missionary Factor in Ethiopia. Papers from a Symposium on the Impact of European Missions on Ethiopian Society. Lund University, August 1996, edited by Getatchew Haile, Aasulv Lande and Samuel Rubenson, 135-154. Frankfurt am Main: Peter Lang, 1998.

Ayele Teklehaymanot. The Ethiopian Church and Its Christological Doctrine. Addis Ababa: Graphic Printers, 1981.

Aymro Wondmagegnehu and Joachim Motovu, ed. The Ethiopian Orthodox Church. Addis Ababa: Ethiopian Orthodox Mission, 1970.

Bahru Zewde. Pioneers of Change in Ethiopia. The Reformist Intellectuals of the Early Twentieth Century. Oxford: Oxford University Press, 2002.

Balisky, Paul. Wolaitta Evangelists. A Study of Religious Innovation in Southern Ethiopia, 1937-1975. Eugene, OR: Pickwick, 2009.

Cohen, Leonardo. The Missionary Strategies of the Jesuits in Ethiopia (1555-1632). Wiesbaden: Harrassowitz, 2009.

Crummey, Donald. Priests and Politicians. Protestant and Catholic Missions in Orthodox Ethiopia 1830-1868. Oxford: Clarendon Press, 1972.

"Ethiopia." The Hierarchy of the Catholic Church, accessed 10.03.2019. URL: http://www .catholic-hierarchy.org/country/det2.html.

"Ethiopian Evangelical Church Mekane Yesus (E ECMY)." The World Council of Churches, accessed 12.03.209. URL: https://www.oikoumene.org/en/member-churches/ethiop ian-evangelical-church-mekane-yesus.

Getatchew Haile. "The Missionary Dream. An Ethiopian Perspective on Western Missions in Ethiopia." In The Missionary Factor in Ethiopia. Papers from a Symposium on the Impact of European Missions on Ethiopian Society. Lund University, August 1996, edited by Getatchew Haile, Aasulv Lande and Samuel Rubenson, 1-8. Frankfurt am Main: Peter Lang, 1998.

Haustein, Jörg. Writing Religious History. The Historiography of Ethiopian Pentecostalism. Harrassowitz: Wiesbaden, 2011.

Jones, Arnold, and Elizabeth Monroe. A History of Ethiopia. Oxford: Clarendon Press, 1935 .

Manastireanu, Danut. "Lausanne Initiative to Bring Together Orthodox and Evangelical Leaders in Ethiopia." Lausanne Orthodox Initiatives, accessed 15.06.2019. URL: https://danutm.wordpress.com/2016/o3/21/lausanne-initiative-to-bring-together-o rthodox-and-evangelical-leaders-in-ethiopia.

Petros Berga. Ecumenical Dialogue in the Rapidly Changing Ethiopia. Addis Ababa: Master Printing Press, 2014.

Rubenson, Sven. "The Missionary Factor in Ethiopia. Consequences of a Colonial Con- 
test." In The Missionary Factor in Ethiopia. Papers from a Symposium on the Impact of European Missions on Ethiopian Society. Lund University, August 1996, edited by Getatchew Haile, Aasulv Lande and Samuel Rubenson, 55-70. Frankfurt am Main: Peter Lang, 1998.

Shenk, Calvin. "The Ethiopian Orthodox Church: A Study in Indigenization." Practical Anthropology 16, no. 3 (1988): 259-278.

Strauss, Stephen. Perspectives on the Nature of Christ in the Ethiopian Orthodox Church. A case Study in Contextualized Theology. Ph.D. Dissertation, Deerfield, IL: Trinity International University, 1997.

Taddesse Tamrat. "Evangelizing the Evangelized. The Root Problem between Missions and the Ethiopian Orthodox Church." In Ethiopia and the Missions. Historical and Anthropological Insights, edited by Verena Böll, Steven Kaplan, Andreu Martínez d'Alòs-Moner and Evgenia Sokolinskaia, 17-30. Münster: Lit, 2005.

The Ethiopian Orthodox Tewahedo Church, ed. The Ethiopian Orthodox Tewahedo Church. Faith, Order of Worship and Ecumenical Relations. 2nd ed. Addis Ababa: Tansae Publishing House, 1996.

The Gudina Tumsa Foundation, ed. The Life and Ministry of Gudina Tumsa. Lectures and Discussions. Hamburg: WDL-Publishers, 2007.

Tibebe Eshete. The Evangelical Movement in Ethiopia. Resistance and Resilience. Waco, TX: Baylor University Press, 2009.

Tsega Endalew. "Protestant Mission Activities and Persecutions in Bahər Dar, 19681994. A Chronicle." In Ethiopia and the Missions. Historical and Anthropological Insights, edited by Verena Böll, Steven Kaplan, Andreu Martínez d'Alòs-Moner and Evgenia Sokolinskaia, 209-220. Münster: Lit, 2005.

Tsion Alemayehu. "Ethiopian Church Fosters Peace and Reconciliation in Gambella." The Lutheran World Federation, published 07.07.2016. URL: https://www.lutheranwo rld.org/news/ethiopian-church-fosters-peace-and-reconciliation-gambella. 